\title{
The Implementation of Value for Money Quantitative Analysis on Infrastructure Projects in Indonesia
}

\section{Case Study of Trans Sumatera Toll Road Project -Section of Palembang Indralaya}

\author{
A. Jefry ${ }^{1}$, Leni Sagita ${ }^{2}$, Andre Permana ${ }^{3}$ \\ 1,2. Program Studi Teknik Sipil, Departemen Teknik Sipil, Fakultas Teknik, Universitas Indonesia, \\ Depok, 16424, Indonesia \\ 3. PT Penjaminan Infrastruktur Indonesia (Persero), Jakarta, Indonesia \\ Corresponding author: \\ a.jefry15@gmail.com
}

\section{ABSTRACT}

Prior to the decision of the Government to opt for PPP (Public Private Partnership) for the procurement scheme of a public infrastructure project, it is necessary to conduct the Value for Money (VfM) analysis. VfM is defined by Moralos and Amekudzi (2008) as the optimum combination of all costs during the life cycle and the quality with the objective to meet the demand of users. According to Pangeran (2010), VfM has only been used in a few cases where the conventional methods, which does not taken into account the risks of the project and only focus on the financial side, is more prevalent. Such test using conventional methods may risk on the non-optimal impact on the benefits from a public procurement projects. In the context of procurement schemes for infrastructure projects in Indonesia, the Government has decided use the BUMN (State-Owned Enterprise) assignment scheme to undertake the Trans Sumatera toll road project as mandated in the Perpres (Presidential Decree) no.100/2014. This paper will review the VfM test for Palembang Indralaya Toll Road (which is a section of the grand Trans Sumatra toll road) where the optimal VFM at 46\% is generated at the BUMN assignment scheme higher than the PPP or APBN (State Budget) option.

Keywords: Value for Money Analysis, PPP, BUMN Assignment, APBN/APBD, risk, modality scheme, Trans Sumatera Toll Road, Palembang-Indralaya

\section{SARI PATI}

Sebelum opsi pengadaan suatu proyek infrastruktur publik ditentukan oleh Pemerintah menggunakan skema pengadaan KPBU (Kerjasama Pemerintah Badan Usaha) atau PPP (Public Private Partnership), pada dasarnya terlebih dahulu perlu dilakukan sebuah evaluasi, yaitu Value for Money (VfM) analysis. VfM didefinisikan oleh Moralos dan Amekudzi (2008) sebagai kombinasi optimum dari seluruh biaya pada siklus hidup dan kualitas bertujuan untuk pemenuhan permintaan pengguna. Pengujian dengan metode konvensional tersebut, dapat berdampak tidak optimalnya manfaat dari pengadaan proyek publik. Mengacu pada kasus pemilihan skema pengadaan proyek infrastruktur di Indonesia, proyek jalan tol Trans Sumatera telah diputuskan oleh Pemerintah melalui Perpres 100 tahun 2014 untuk dilaksanakan dengan skema penugasan BUMN. Paper ini mengulas uji VfM untuk Jalan Tol Palembang Indralaya (bagian dari ruas tol Trans Sumatra) dimana VfM yang optimal dihasilkan pada opsi skema penunjukan BUMN, yaitu sebesar 46\%, dibandingkan opsi skema KPBU dan skema APBN.

Kata Kunci: Value for Money Analysis, KPBU, Penugasan BUMN (Badan Usaha Milik Negara), APBN/APBD, risiko, skema modalitas, Jalan Tol Trans Sumatera Ruas Palembang-Indralaya 


\section{INTRODUCTION}

PPP (Public Private Partnership) scheme is often seen as a fairly effective option to get a better added value in the form of value for money for public infrastructure projects. The advantages come from the tender process and from the possible efficiency and innovation that the private sector can offer. The approach toward risk between the public sector (government) and the private sector is the key to create this value for money. This is due to different nature between PPP and traditional procurement (or public procurement in general). Traditional procurement usually separates the design and the construction tender, meanwhile within the PPP scheme, the contract is often developed between the private partner and the Government without a prior complete information as the basis (Pangeran and Wirahadikusumah, 2010). VfM is defined by Moralos and Amekudzi (2008) as the optimum combination of all costs during the life cycle and the quality which aims to meet the demand of users. Hui et al (2010) states that VfM is a tool to assess whether a project will bring maximum benefit from its products and services, and that the selection of private partner is not based on the bid with the lowest cost but based on certain other criteria.

Considering the potential implementation of private-public cooperation on public infrastructure projects in Indonesia, and the importance of VfM test before opting for a PPP scheme, the Government should conduct an in-depth evaluation of VfM Analysis on its infrastructure projects. According to Pangeran (2010), in a few cases VfM has been calculated using conventional methods which does not taken into account the risks of the project, and only focuses on the financial side only. Such test using conventional methods may risk on the non-optimal impact of the benefits from a public procurement project.

The provision of road infrastructure in Indonesia so far has not progressed in line with the target.
For more than 30 years since the construction and operation of the first toll road, the number has only reached about 774 kilometers until 2011 (BPJT, 2012). The provision of road infrastructure through the PPP scheme is currently regulated in Perpres 38/2015 on Government Cooperation with Business Entities in the Provision of Infrastructure. As one of the infrastructure projects in Indonesia, the Government has decided that the Trans Sumatera toll road project will be implemented under a BUMN assignment scheme. In Perpres 100/2014 on the Acceleration of Toll Road Construction in Sumatra, PT. Hutama Karya (Persero) was appointed to carry out the development of four toll road segments in Sumatera: Medan-Binjai, Palembang-Indralaya, Bakauheni-Terbanggi Besar and Pekanbaru-Dumai.

This paper reviews the implementation of Value for Money Analysis in the process of selecting the modalities for public infrastructure projects, i.e. between the APBN/APBD scheme, BUMN assignment or PPP. The analysis includes the process of quantifying risk factors from each option (APBN/APBD, BUMN assignment and PPP) as one of the quantitative VfM drivers for the project. It is expected that the results of this VFM analysis will be taken into account for choosing the optimal funding strategy for this project (Palembang-Indralaya Section Toll Road). The researchers will collect data of investment costs and risks that affect the investment costs. The independent variables in this study will be the public sector comparator and risk factors that will affect the cost of a case study on infrastructure projects. The dependent variable in this study is the most optimal VfM value of the three project financing schemes. This research will also conduct the risk calculation analysis and the life cycle cost calculation analysis using spreadsheet model.

\section{Theoretical Review}

The term VfM is often defined in some literatures 
as the optimum combination of all cost of life cycle, risk, time and project quality which seeks to meet the public demand, as well as the consideration prior to carrying out a project under the a PPP scheme (Grimsey and Lewis, 2004). Moralos and Amekudzi (2008) define VfM as the best available way to get cost savings, benefits and risk allocations during project life time that focus on quality and competence in meeting the public demand.

By applying the VfM test before the choosing the modality of a public project, according to HM Treasury (2009), the government can save a sum of approximately $£ 35 \mathrm{M}$ in the 2010-2011 period, by focusing not only on the construction aspects, but also by considering other areas.

In its implementation, VfM consists of 3 main elements: PSC and PPP. The PSC has several specific constituent components such as raw PSC, transferable risk, retained risk, and competitive neutrality, meanwhile the PPP has different constituent components such as service payment, which is identical to Raw PSC, and retained risk. The following is the explanation of each component:

\section{Raw PSC and Service Payment}

This component is often called base cost or basic cost of a project that includes all initial investment and operational costs such as building, ownership cost, maintenance cost, and required cost for service at a specified time (Hui, et al, 2010). The component is calculated based on the aggregate of cash flow, without involving the possible risks. Table 1 shows the complete elements which are entered into the calculation as stated by the Department of Treasury of the Government of Western Australia, (2011).

Table 1. The elements in Raw PSC and Service Payment Calculation

\begin{tabular}{|c|c|c|}
\hline & Input Assumption & Note \\
\hline $\begin{array}{l}\text { General } \\
\text { Assumption }\end{array}$ & Inflation & $\begin{array}{l}\text { Inflation rate should be based on the projection } \\
\text { of the state budget. }\end{array}$ \\
\hline \multirow{5}{*}{$\begin{array}{l}\text { Direct Capital } \\
\text { Cost }\end{array}$} & Construction and commission & \multirow{3}{*}{$\begin{array}{l}\text { The referenced project should as similar as } \\
\text { possible and can be implemented in this project }\end{array}$} \\
\hline & Raw material & \\
\hline & Design and Project Planning & \\
\hline & Pre-project Consultation Cost & $\begin{array}{l}\text { Consultation is taken into account when it is } \\
\text { directly related to the upcoming public project. }\end{array}$ \\
\hline & Contingency Cost & $\begin{array}{l}\text { This is not included in PSC and PPP project, } \\
\text { including the risk-related cost. Within the } \\
\text { calculation for PSC and PPP project, all is } \\
\text { considered running according to the budget. }\end{array}$ \\
\hline Capital Receipt & Residual Value & $\begin{array}{l}\text { If any asset has reached its life time or no } \\
\text { longer in use, its present residual value will be } \\
\text { calculated. }\end{array}$ \\
\hline \multirow{3}{*}{$\begin{array}{l}\text { Maintenance } \\
\text { and Life-cycle } \\
\text { cost }\end{array}$} & Initial Cost and Maintenance & $\begin{array}{l}\text { The level of maintenance and the life cycle cost } \\
\text { should be in accordance with capital, projected } \\
\text { Opex and residual value. }\end{array}$ \\
\hline & Lifecycle Financing & $\begin{array}{l}\text { Financing costs incurred to maintain the } \\
\text { project's quality and capability. }\end{array}$ \\
\hline & Maintenance Labor & Salary for maintenance workers \\
\hline \multirow{3}{*}{$\begin{array}{l}\text { Direct } \\
\text { Operational Cost }\end{array}$} & Direct Project Cost & $\begin{array}{l}\text { Expenditure for raw material, management cost } \\
\text { and all other direct project cost. }\end{array}$ \\
\hline & Direct Project Labor & Salary for project workers. \\
\hline & Insurance & Insurance for project risks. \\
\hline Indirect Cost & Overhead Cost & $\begin{array}{l}\text { Costs that are not directly related to the course of } \\
\text { the project. }\end{array}$ \\
\hline Revenue & $\begin{array}{l}\text { Third Party request related to Infrastructure } \\
\text { The Government is allowed to engage a Third } \\
\text { Party }\end{array}$ & $\begin{array}{l}\text { Project guide in order to reduce the operational } \\
\text { cost of PSC and PPP Service Payment. }\end{array}$ \\
\hline
\end{tabular}

Source: National Public Private Partnership Guidelines, Government of Western Australia (2011) 


\section{Competitive Neutrality}

This aspect only counts on the PSC, which is the value of the competitive advantages and disadvantages gained by the government from the ownership of a public project (Hui, et al, 2010). The elements shown in table 2 are taken into account in Competitive Neutrality by the Government of Western Australia. (Department of Treasury, 2011).

\section{Transferable Risk dan Retained Risk}

According to Hui, et al (2010) transferable risk represents the value of each risk when transferred to private bidders and this only counts on a PSC project. Meanwhile retained risk is defined by Grimsey and Lewis (2005) as all risks that are not delegated to private partner or borne by the government, and are taken into account in PSC and PPP project. A project modality requires such detailed data collection of possible risks, and must analyze the impact and probability of occurrence of each risk. Figure 1 shows a comparative illustration of the main building elements of PSC project, BUMN assignment project and PPP project.

\section{RESULT AND DISCUSSION}

Based on data collected from literature and previous research, there are 21 risk factor variables that may influence the investment cost on Palembang-Indralaya toll road. The initial validation was carried out by 7 experts. Out of this 21 variables, the experts have chosen 13 variables that have the potential risk in increasing the toll road cost. These 13 variables will then be used for survey pilots and respondent questionnaires, see Table3.

In addition, the experts also allocate the risk of these factors that may affect the investment costs. The result is as given in Table 4 .

Table 2. Elements in Calculating the Competitive Neutrality

\begin{tabular}{|c|c|c|}
\hline No. & Insurance Input & Note \\
\hline 1. & Land and Building Tax & \multirow{3}{*}{$\begin{array}{l}\text { Only take into account the advantage gained by } \\
\text { governments which are not available to private } \\
\text { bidders }\end{array}$} \\
\hline 2. & Income Tax & \\
\hline 3. & Material or Administration & \\
\hline
\end{tabular}

Source: National Public Private Partnership Guidelines, Government of Western Australia (2011)

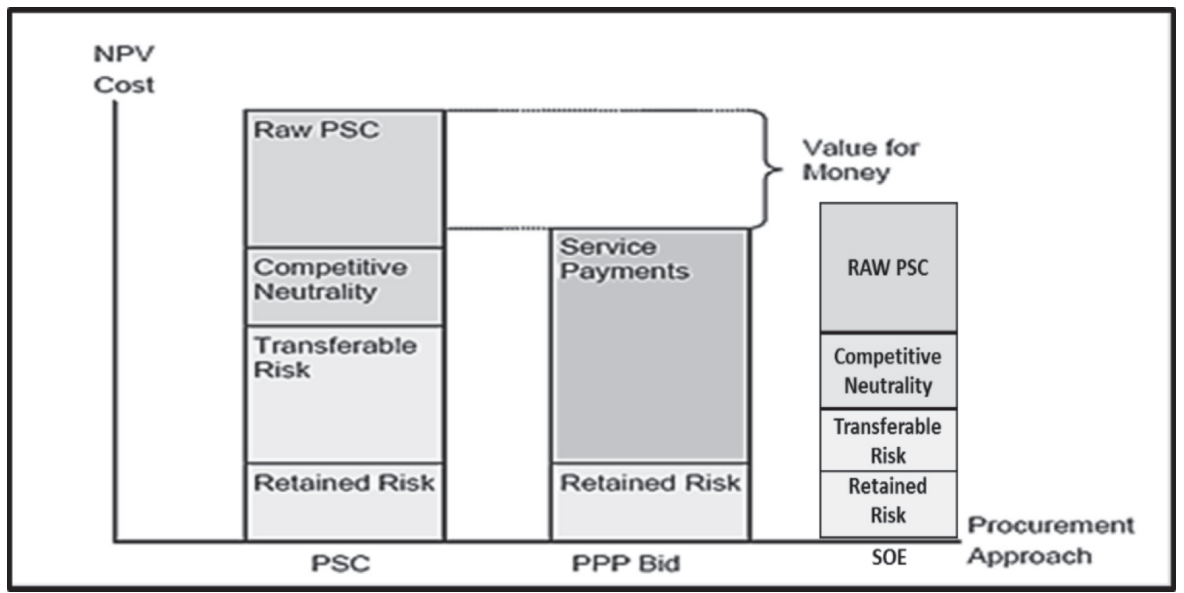

Figure 1 Main building elements of PSC project Source: Morales, 2009 
Table 3. Variables Validated by Experts

\begin{tabular}{|c|c|c|c|c|c|c|c|c|c|}
\hline No & Risk Factor & P1 & P2 & P3 & P4 & P5 & P6 & P7 & Conclution \\
\hline \multicolumn{10}{|c|}{ LOCATION RISK } \\
\hline 1 & Land Acquisition Risk & $\sqrt{ }$ & $\sqrt{ }$ & $\sqrt{ }$ & $\sqrt{ }$ & $\sqrt{ }$ & $\sqrt{ }$ & $\mathrm{x}$ & influential \\
\hline \multicolumn{10}{|c|}{ RISK OF CONSTRUCTION DESIGN, CONSTRUCTION PERIOD AND COMMISSIONING } \\
\hline 2 & Planning Risk & $\sqrt{ }$ & $\sqrt{ }$ & $\sqrt{ }$ & $\sqrt{ }$ & $\sqrt{ }$ & $\sqrt{ }$ & $\mathrm{V}$ & influential \\
\hline 3 & Design Risk & $\sqrt{ }$ & $\sqrt{ }$ & $\sqrt{ }$ & $\mathrm{X}$ & $\sqrt{ }$ & $\sqrt{ }$ & $\mathrm{X}$ & influential \\
\hline 4 & Increased Cost Risk & $\sqrt{ }$ & $\sqrt{ }$ & $\sqrt{ }$ & $\sqrt{ }$ & $\sqrt{ }$ & $\sqrt{ }$ & $\mathrm{x}$ & influential \\
\hline \multicolumn{10}{|c|}{ SPONSOR RISK } \\
\hline 5 & Sponsor Risk & $\sqrt{ }$ & $\sqrt{ }$ & $\mathrm{x}$ & $\mathrm{x}$ & $\sqrt{ }$ & $\sqrt{ }$ & $\sqrt{ }$ & influential \\
\hline \multicolumn{10}{|c|}{ FINANCIAL RISK } \\
\hline 6 & Financial Parameter Risk & $\sqrt{ }$ & $\sqrt{ }$ & $\sqrt{ }$ & $\sqrt{ }$ & $\sqrt{ }$ & $\mathrm{x}$ & $\sqrt{ }$ & influential \\
\hline \multicolumn{10}{|c|}{ OPERATIONAL RISK } \\
\hline 7 & Maintenance Risk & $\sqrt{ }$ & $\sqrt{ }$ & $\mathrm{x}$ & $\sqrt{ }$ & $\sqrt{ }$ & $\sqrt{ }$ & $\mathrm{x}$ & influential \\
\hline 8 & Technology Risk & $\sqrt{ }$ & $\sqrt{ }$ & $\sqrt{ }$ & $\mathrm{x}$ & $\sqrt{ }$ & $\sqrt{ }$ & $\mathrm{x}$ & influential \\
\hline 9 & Utility Risk & $\sqrt{ }$ & $\sqrt{ }$ & $\mathrm{x}$ & $\mathrm{x}$ & $\sqrt{ }$ & $\sqrt{ }$ & $\mathrm{x}$ & influential \\
\hline \multicolumn{10}{|c|}{ MARKET AND REVENUE RISK } \\
\hline 10 & $\begin{array}{l}\text { Lower demand risk } \\
\text { (from original estimation) }\end{array}$ & $\mathrm{X}$ & $\sqrt{ }$ & $\sqrt{ }$ & $\mathrm{x}$ & $\sqrt{ }$ & $\mathrm{x}$ & $\mathrm{X}$ & influential \\
\hline \multicolumn{10}{|c|}{ POLITICAL RISK } \\
\hline 11 & Sub-sovereign or parastatal risk & $\sqrt{ }$ & $\sqrt{ }$ & $\sqrt{ }$ & $\mathrm{x}$ & $\mathrm{V}$ & $\mathrm{x}$ & $x$ & influential \\
\hline \multicolumn{10}{|c|}{ FORCE MAJEUR RISK } \\
\hline 12 & Natural disaster (causing delay) & $\sqrt{ }$ & $\sqrt{ }$ & $\sqrt{ }$ & $\sqrt{ }$ & $\sqrt{ }$ & $\sqrt{ }$ & $\sqrt{ }$ & influential \\
\hline 13 & Defaulted developer during its contract period & $\sqrt{ }$ & $\sqrt{ }$ & $\sqrt{ }$ & $\mathrm{x}$ & $\sqrt{ }$ & $\sqrt{ }$ & $\sqrt{ }$ & influential \\
\hline
\end{tabular}

Table 4. Risk Allocation

\begin{tabular}{|c|c|c|c|c|c|c|c|c|c|}
\hline No & Risk & P1 & P2 & P3 & P4 & P5 & P6 & P7 & Conclution \\
\hline \multicolumn{10}{|c|}{ LOCATION RISK } \\
\hline 1 & Land Acquisition Risk & $\mathrm{R}$ & $\mathrm{R}$ & $\mathrm{R}$ & $\mathrm{R}$ & $\mathrm{R}$ & $\mathrm{R}$ & $\mathrm{R}$ & Retained by government \\
\hline \multicolumn{10}{|c|}{ RISK OF CONSTRUCTION DESIGN, CONSTRUCTION PERIOD AND COMMISSIONING } \\
\hline 2 & Planning Risk & $\mathrm{R}$ & $\mathrm{T}$ & $\mathrm{T}$ & $\mathrm{R}$ & $\mathrm{T}$ & $\mathrm{R}$ & $\mathrm{R}$ & Retained by government \\
\hline 3 & Design Risk & $\mathrm{R}$ & $\mathrm{T}$ & $\mathrm{T}$ & $\mathrm{T}$ & $\mathrm{T}$ & $\mathrm{T}$ & $\mathrm{T}$ & Transferred to private partner \\
\hline 4 & Increased Cost Risk & $\mathrm{R}$ & $\mathrm{T}$ & $\mathrm{T}$ & $\mathrm{R}$ & $\mathrm{R}$ & $\mathrm{T}$ & $\mathrm{T}$ & Transferred to private partner \\
\hline \multicolumn{10}{|c|}{ SPONSOR RISK } \\
\hline 5 & Sponsor Risk & $\mathrm{T}$ & $\mathrm{T}$ & $\mathrm{R}$ & $\mathrm{R}$ & $\mathrm{T}$ & $\mathrm{T}$ & $\mathrm{T}$ & Transferred to private partner \\
\hline \multicolumn{10}{|c|}{ FINANCIAL RISK } \\
\hline 6 & Financial Parameter Risk & $\mathrm{T}$ & $\mathrm{T}$ & $\mathrm{T}$ & $\mathrm{R}$ & $\mathrm{T}$ & $\mathrm{T}$ & $\mathrm{T}$ & Transferred to private partner \\
\hline \multicolumn{10}{|c|}{ OPERATIONAL RISK } \\
\hline 7 & maintenance Risk & $\mathrm{T}$ & $\mathrm{T}$ & $\mathrm{T}$ & $\mathrm{R}$ & $\mathrm{T}$ & $\mathrm{T}$ & $\mathrm{T}$ & Transferred to private partner \\
\hline 8 & Technology Risk & $\mathrm{T}$ & $\mathrm{T}$ & $\mathrm{T}$ & $\mathrm{T}$ & $\mathrm{T}$ & $\mathrm{T}$ & $\mathrm{T}$ & Transferred to private partner \\
\hline 9 & Utility Risk & $\mathrm{T}$ & $\mathrm{T}$ & $\mathrm{T}$ & $\mathrm{T}$ & $\mathrm{T}$ & $\mathrm{T}$ & $\mathrm{T}$ & Transferred to private partner \\
\hline \multicolumn{10}{|c|}{ MARKET AND REVENUE RISK } \\
\hline 10 & $\begin{array}{l}\text { Lower demand risk (from } \\
\text { original estimation) }\end{array}$ & $\mathrm{T}$ & $\mathrm{T}$ & $\mathrm{T}$ & $\mathrm{T}$ & $\mathrm{T}$ & $\mathrm{T}$ & $\mathrm{R}$ & Transferred to private partner \\
\hline \multicolumn{10}{|c|}{ POLITICAL RISK } \\
\hline 11 & Sub-sovereign or parastatal risk & $\mathrm{R}$ & $\mathrm{T}$ & $\mathrm{R}$ & $\mathrm{R}$ & $\mathrm{R}$ & $\mathrm{R}$ & $\mathrm{R}$ & Retained by government \\
\hline \multicolumn{10}{|c|}{ FORCE MAJEUR RISK } \\
\hline 12 & Natural disaster (causing delay) & $\mathrm{T}$ & $\mathrm{T}$ & $\mathrm{T}$ & $\mathrm{R}$ & $\mathrm{T}$ & $\mathrm{R}$ & $\mathrm{R}$ & Transferred to private partner \\
\hline 13 & $\begin{array}{l}\text { Defaulted developer during its } \\
\text { contract period }\end{array}$ & $\mathrm{T}$ & $\mathrm{T}$ & $\mathrm{T}$ & $\mathrm{R}$ & $\mathrm{T}$ & $\mathrm{T}$ & $\mathrm{T}$ & Transferred to private partner \\
\hline
\end{tabular}


A pilot survey is conducted to 10 potential respondents before a questionnaire is distributed to 30 actual respondents. The result of this questionnaire distribution is then tested using statistic test such as validity and reliability test where it gives a Cronbach's Alpha value above 0.361 with 13 variables. Based on the Cronbach's Alpha Method Reliability Level table, this instrument can be categorized as 'very reliable'. After the variables are tested for their validity and reliability, the data is processed through Montecarlo analysis using a crystal ball program to give their probability value.

Table 5. Result of Montecarlo Analysis

\begin{tabular}{lr}
\hline Statistic & Forecast values \\
\hline Trials & 1,000 \\
\hline Base Case & 3.6 \\
\hline Mean & 3 \\
\hline Median & 3 \\
\hline Mode & \\
\hline Standard Deviation & 0.05 \\
\hline Variance & 0 \\
\hline Skewness & -0.0374 \\
\hline Kurtosis & 3 \\
\hline Coeff. of Variability & 0.0178 \\
\hline Minimum & 2.83 \\
\hline Maximum & 3.17 \\
\hline Mean Std. Error & 0 \\
\hline
\end{tabular}

Now we have the information on the influence and the frequency of the risk, and these parameters are multiplied by the cost. The result is quantified risk as shown in Table 6.

This data of quantified risk from the respondents' questionnaire are then entered into a spreadsheet model, with the results as shown in Table 7.

Once the investment cost or CAPEX (Capital Expenditure) is found out, next data is the operational costs until the end of the concession or OPEX (Operational Expenditure). Figure 2 shows the projected operational costs of the
Palembang-Indralaya toll road.

The result of the calculation of competitive neutrality shows that the greatest value is income tax of IDR 9.9 trillion for 40 years or IDR 1.2 trillion at its net present value, see Table 8 .

The non-risk adjusted PSC is calculated at the value of IDR 7 trillion at its net present value. The next step is calculating the risk value of PSC, as presented in Figure 3.

From the calculation of risks transferred to the private partners, the result shows the risk values as shown in Figure 3, which consists of design risk, sponsor risk, financial parameter risk, technology risk, utility risk, lower demand risk, natural disaster, defaulted developer and maintenance risk. From Figure 3, maintenance risk makes up the biggest value at IDR 470.7 billion.

From the calculation of risks transferred to the private partners, the result shows the risk values as shown in Figure 3, which consists of design risk, sponsor risk, financial parameter risk, technology risk, utility risk, lower demand risk, natural disaster, defaulted developer and maintenance risk. From Figure 4, maintenance risk makes up the biggest value at IDR 470.7 billion.

From the calculation of risks retained by the Government, the result shows the risk values as shown in Figure 4, which consist of land acquisition risk, planning risk, cost increase risk and sub-sovereign or parastatal risk. From Figure 5, sub-sovereign or parastatal risk makes up the biggest value at IDR 603.3 billion.

Afterwards we obtain the PSC value calculation at IDR 8 trillion from the combination of CAPEX, OPEX and the previously quantified risks. This PSC value will be compared with the Availability Payment value if the project uses a PPP scheme, 
where the calculation of Availability Payment is given as shown in Figure 4.

\section{Discussion}

The quantifiable risk factors have been identified

through the validation process by the experts,

Table 6. Result of Quantified Risks

\begin{tabular}{|c|c|c|c|c|c|c|c|c|}
\hline Allocation & Type of Risk & Description & Expenditure & Initial Cost & Account & Influence & Freq. & Value \\
\hline $\begin{array}{l}\text { Retained by } \\
\text { government }\end{array}$ & $\begin{array}{l}\text { Land } \\
\text { Acquisition } \\
\text { Risk }\end{array}$ & $\begin{array}{c}\text { Prolonged land } \\
\text { acquisition process } \\
\text { causing delay and } \\
\text { increased project cost }\end{array}$ & CAPEX & $(59,274)$ & $\begin{array}{l}\text { Overhead } \\
\text { cost on } \\
\text { construction }\end{array}$ & 0.134 & 0.838 & $(6,655.97)$ \\
\hline $\begin{array}{l}\text { Retained by } \\
\text { government }\end{array}$ & $\begin{array}{l}\text { Planning } \\
\text { Risk }\end{array}$ & $\begin{array}{l}\text { Project does not } \\
\text { comply to regulation } \\
\text { in terms of spatial } \\
\text { planning, land use, or } \\
\text { problems in permit } \\
\text { issuance (delayed, } \\
\text { rejected or obtained } \\
\text { at a very high cost) }\end{array}$ & CAPEX & $(59,274)$ & $\begin{array}{l}\text { Overhead } \\
\text { cost on } \\
\text { construction }\end{array}$ & 0.286 & 0.502 & $(8,510.05)$ \\
\hline $\begin{array}{l}\text { Retained by } \\
\text { government }\end{array}$ & $\begin{array}{l}\text { Increased } \\
\text { Cost Risk }\end{array}$ & $\begin{array}{c}\text { The actual } \\
\text { engineering and } \\
\text { construction cost } \\
\text { is higher than } \\
\text { previously calculated }\end{array}$ & CAPEX & $(116,696)$ & $\begin{array}{l}\text { Escalated } \\
\text { construction } \\
\text { cost }\end{array}$ & 0.276 & 0.567 & $(18,261.97)$ \\
\hline $\begin{array}{l}\text { Retained by } \\
\text { government }\end{array}$ & $\begin{array}{l}\text { Sub- } \\
\text { sovereign or } \\
\text { Parastatal } \\
\text { Risk }\end{array}$ & $\begin{array}{l}\text { The government is } \\
\text { unable/refuses to } \\
\text { deliver the contract } \\
\text { payment or other } \\
\text { material liabilities } \\
\text { due to its status as } \\
\text { government entity }\end{array}$ & OPEX & $(2,892,277)$ & $\begin{array}{l}\text { Total cost of } \\
\text { operation }\end{array}$ & 0.351 & 0.574 & $(582,718.61)$ \\
\hline $\begin{array}{l}\text { Transferred } \\
\text { to private } \\
\text { partner }\end{array}$ & Design Risk & $\begin{array}{c}\text { The original design } \\
\text { is unable to deliver } \\
\text { the specified output/ } \\
\text { requirement }\end{array}$ & CAPEX & $(2,631,006)$ & Construction & 0.189 & 0.548 & $(272,498)$ \\
\hline $\begin{array}{l}\text { Transferred } \\
\text { to private } \\
\text { partner }\end{array}$ & Sponsor Risk & Defaulted sponsor & CAPEX & $(2,631,006)$ & Construction & 0.249 & 0.591 & $(387,176)$ \\
\hline $\begin{array}{l}\text { Transferred } \\
\text { to private } \\
\text { partner }\end{array}$ & $\begin{array}{c}\text { Financial } \\
\text { Parameter } \\
\text { Risk }\end{array}$ & $\begin{array}{l}\text { Risk due to the } \\
\text { fluctuation on } \\
\text { financial parameter } \\
\text { (inflation, market } \\
\text { condition) }\end{array}$ & CAPEX & $(116,696)$ & Escalation & 0.307 & 0.709 & $(25,400)$ \\
\hline $\begin{array}{l}\text { Transferred } \\
\text { to private } \\
\text { partner }\end{array}$ & $\begin{array}{l}\text { Technology } \\
\text { Risk }\end{array}$ & $\begin{array}{l}\text { The technology used } \\
\text { is unable to deliver } \\
\text { the specified output/ } \\
\text { requirement }\end{array}$ & CAPEX & $(55,251)$ & Cost of tools & 0.116 & 0.437 & $(2,800)$ \\
\hline $\begin{array}{l}\text { Transferred } \\
\text { to private } \\
\text { partner }\end{array}$ & Utility Risk & $\begin{array}{l}\text { Risk of unavailable } \\
\text { utility (water, } \\
\text { electricity, gas) or } \\
\text { project delay due to } \\
\text { relocation }\end{array}$ & OPEX & $(465,901)$ & $\begin{array}{l}\text { Toll service } \\
\text { cost }\end{array}$ & 0.198 & 0.477 & $(44,002)$ \\
\hline $\begin{array}{l}\text { Transferred } \\
\text { to private } \\
\text { partner }\end{array}$ & $\begin{array}{c}\text { Lower } \\
\text { Demand Risk }\end{array}$ & $\begin{array}{l}\text { The actual demand } \\
\text { of service is } \\
\text { unexpectedly } \\
\text { lower than original } \\
\text { estimation }\end{array}$ & OPEX & $(606,636)$ & $\begin{array}{l}\text { Overhead cost } \\
\text { on operation }\end{array}$ & 0.282 & 0.526 & $(89,983)$ \\
\hline $\begin{array}{l}\text { Transferred } \\
\text { to private } \\
\text { partner }\end{array}$ & $\begin{array}{l}\text { Natural } \\
\text { Disaster }\end{array}$ & $\begin{array}{l}\text { Natural disaster } \\
\text { causing project delay }\end{array}$ & OPEX & $(65,775)$ & $\begin{array}{c}\text { Overhead } \\
\text { cost on } \\
\text { construction }\end{array}$ & 0.367 & 0.5 & $(12,069)$ \\
\hline
\end{tabular}




\begin{tabular}{|c|c|c|c|c|c|c|c|c|}
\hline Allocation & Type of Risk & Description & Expenditure & Initial Cost & Account & Influence & Freq. & Value \\
\hline $\begin{array}{c}\text { Transferred } \\
\text { to private } \\
\text { partner }\end{array}$ & $\begin{array}{l}\text { Defaulted } \\
\text { developer } \\
\text { during its } \\
\text { contract } \\
\text { period }\end{array}$ & $\begin{array}{l}\text { Over 6-12 months } \\
\text { may disturb the } \\
\text { economic aspects of } \\
\text { the affected parties }\end{array}$ & OPEX & $(462,434)$ & $\begin{array}{c}\text { Overhead } \\
\text { cost on } \\
\text { administrative } \\
\text { operation }\end{array}$ & 0.307 & 0.635 & $(90,149)$ \\
\hline $\begin{array}{c}\text { Transferred } \\
\text { to private } \\
\text { partner }\end{array}$ & $\begin{array}{c}\text { Maintenance } \\
\text { Risk }\end{array}$ & $\begin{array}{l}\text { The actual } \\
\text { maintenance cost of } \\
\text { the asset is higher } \\
\text { than previously } \\
\text { estimated }\end{array}$ & $\begin{array}{c}\text { OPEX } \\
\text { (Maintenance) }\end{array}$ & $(6,104,772)$ & $\begin{array}{c}\text { Maintenance } \\
\text { cost }\end{array}$ & 0.155 & 0.507 & $(479,743)$ \\
\hline
\end{tabular}

Table 7. Investment Cost Projection

\begin{tabular}{|c|c|c|c|c|}
\hline \multirow{2}{*}{ Description } & \multirow{2}{*}{ Total } & \multicolumn{3}{|c|}{ Year } \\
\hline & & 2015 & 2016 & 2017 \\
\hline Land & - & - & & \\
\hline Planning/Design & 13,155 & 13,155 & & \\
\hline Construction/Facility & $2,631,006$ & 58,287 & $2,107,653$ & 465,066 \\
\hline Toll road tools & 55,251 & - & 32,062 & 23,189 \\
\hline Supervision & 39,465 & 874 & 31,615 & 6,976 \\
\hline Escalation & 131,223 & - & 91,561 & 39,662 \\
\hline VAT (PPN) & 287,010 & 7,232 & 226,289 & 53,489 \\
\hline Overhead & 65,775 & 1,457 & 52,691 & 11,627 \\
\hline Financial Cost & 24,171 & & 12,086 & 12,086 \\
\hline Project Cost before IDC & $3,247,056$ & 81,005 & $2,553,957$ & 612,094 \\
\hline \multicolumn{5}{|l|}{ Investment Source } \\
\hline - SMI Financing (30\%) - Debt & 974,117 & 24,302 & 766,187 & 183,628 \\
\hline - Govt. Financing (70\%) - Equity & $2,272,939$ & 56,704 & $1,787,770$ & 428,466 \\
\hline Total & $3,247,056$ & 81,005 & $2,553,957$ & 612,094 \\
\hline IDC & 54,061 & & 33,024 & 21,037 \\
\hline \multicolumn{5}{|l|}{ IDC Composition } \\
\hline - SMI Financing (30\%) - Debt & 16,218 & - & 9,907 & 6,311 \\
\hline - Govt. Financing (70\%) - Equity & 37,843 & - & 23,117 & 14,726 \\
\hline Total & 54,061 & - & 33,024 & 21,037 \\
\hline \multicolumn{5}{|l|}{ Total } \\
\hline - SMI Financing (30\%) - Debt & 990,335 & 24,302 & 776,094 & 189,939 \\
\hline - Govt. Financing (70\%) - Equity & $2,310,782$ & 56,704 & $1,810,886$ & 443,192 \\
\hline Total Financing & $3,301,117$ & 81,005 & $2,586,981$ & 633,131 \\
\hline
\end{tabular}

Source : Palembang-Indralaya Toll Road Section: Planning 2015

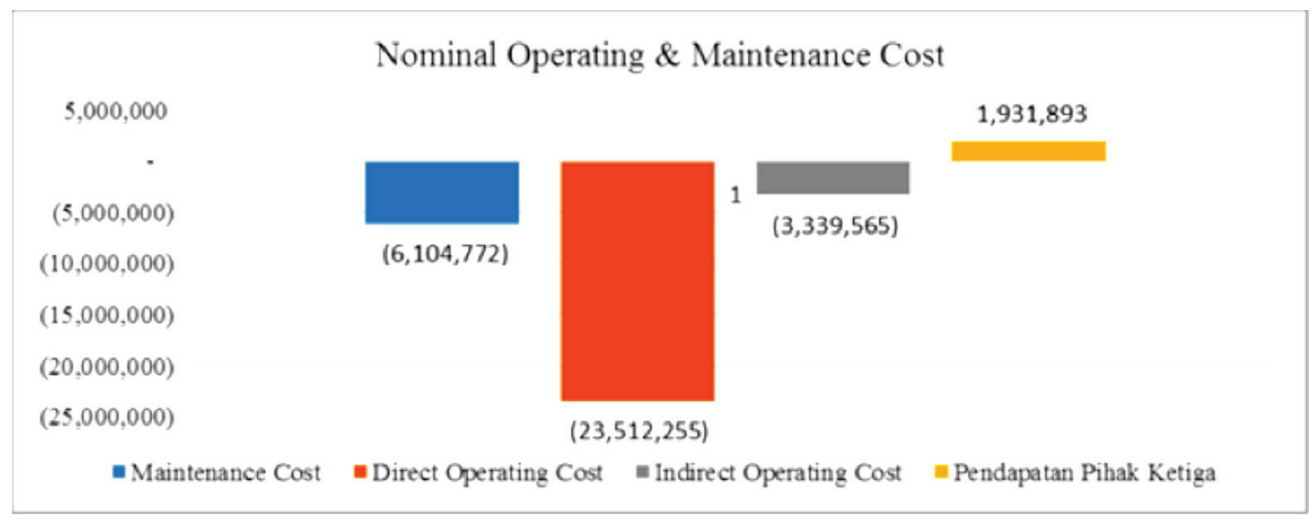

Figure 2 Nominal Operating \& Maintenance Cost Source: Processed data by author, 2017 
Table 8. Competitive Neutrality

\begin{tabular}{lccc}
\hline Competitive Neutrality & Net Present Cost & Nominal & Source \\
\hline Land and Building Tax & $(10,691)$ & $(98,870)$ & \\
\hline $\begin{array}{l}\text { Regional Income Tax } \\
\text { (VAT) 10\% }\end{array}$ & $(252,283)$ & $(287,010)$ & Palindra Business Plan \\
\hline $\begin{array}{l}\text { Permit and } \\
\text { Administration }\end{array}$ & $(1,763)$ & $(16,302.17)$ & Australia Govt. \\
\hline Income Tax (PPh 30\%) & $(1,224,593)$ & $(9,916,867)$ & VFM Palapa Ring (MoF) \\
\hline $\begin{array}{l}\text { Sub Total Competitive } \\
\text { Neutrality }\end{array}$ & $(1,489,330)$ & $(10,319,049)$ & \\
\hline Source : Processed data by author, 2017 & & & \\
\hline
\end{tabular}

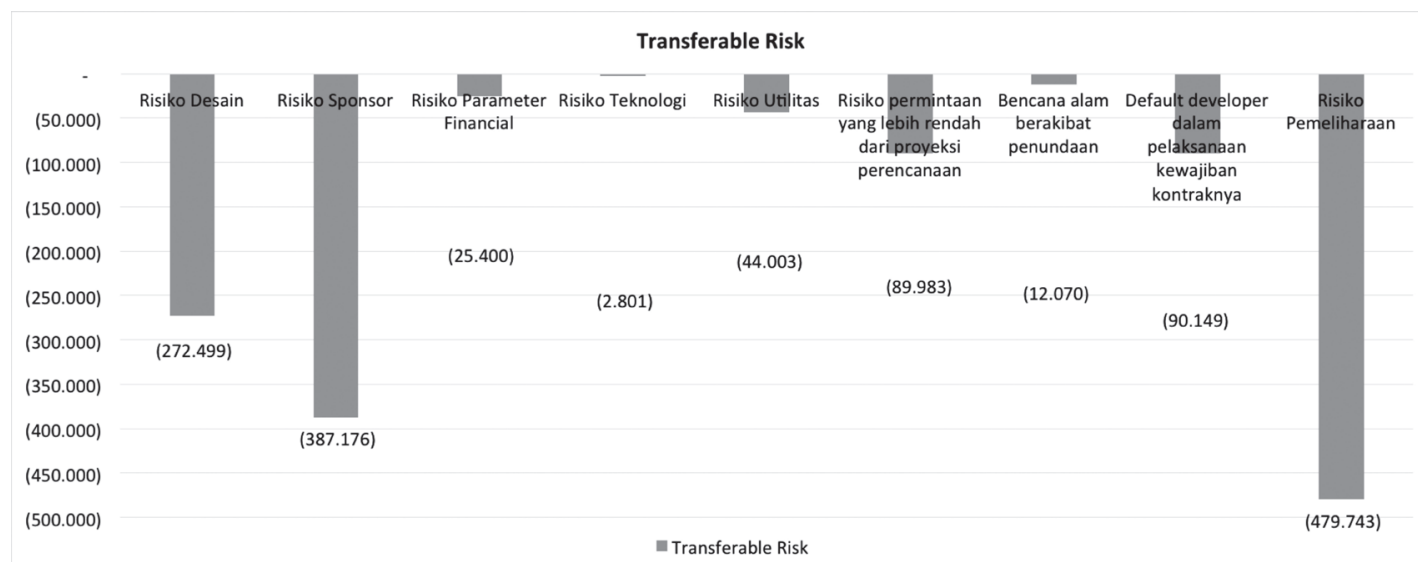

Figure 3 Transferable Risk

Source: Data processed by researchers, 2017

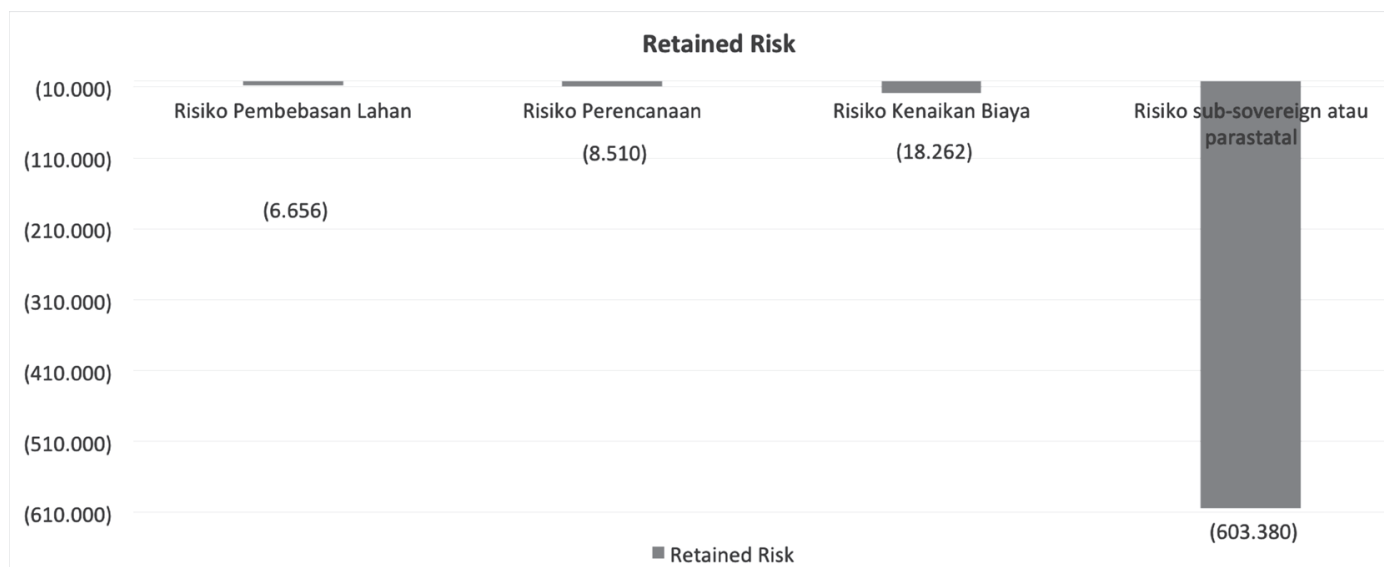

Figure 4. Retained Risk

Source: Data processed by researcher, 2017 


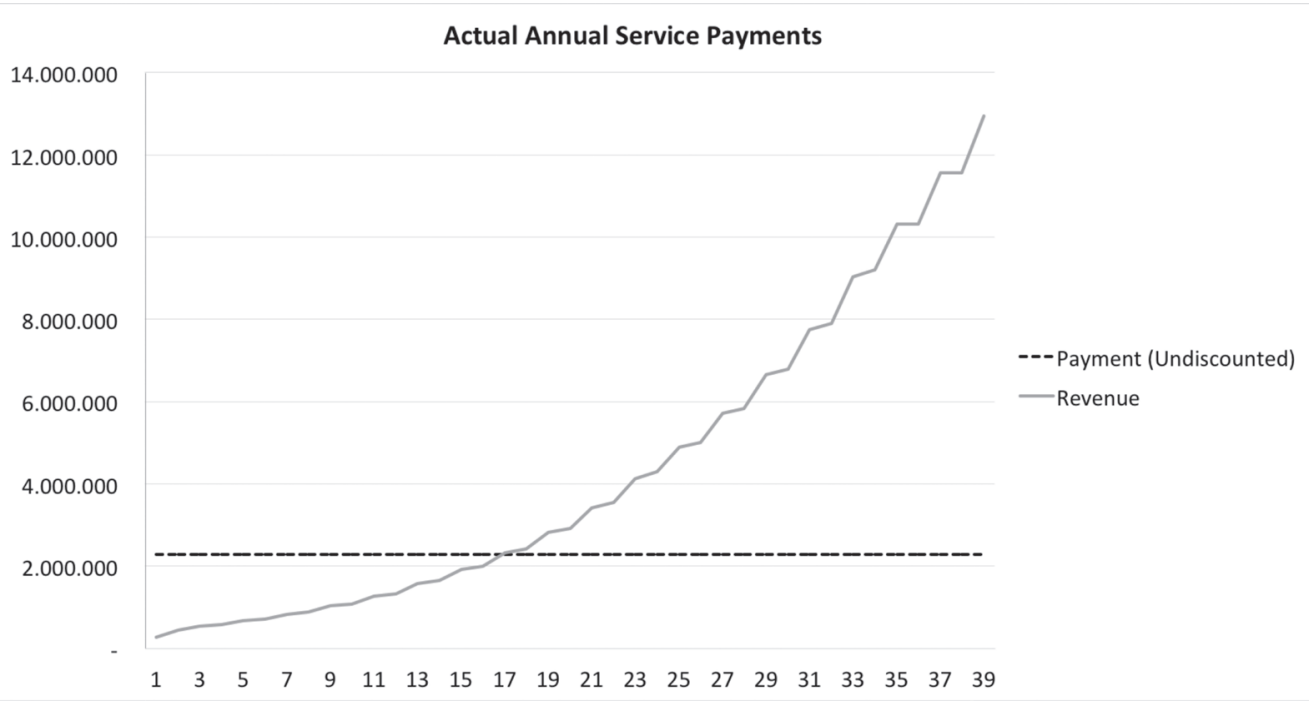

Figure 5. Actual Annual Service Payment Source: Data processed by researcher, 2017

where the biggest risk factors are transferred to the private sector, while the smaller ones are retained by the government.

The main objective of this research is to identify the quantifiable risk factors, and the quantifiable risk factors that may influence the investment cost. The result is as the following:

Table 9. Risks retained by the government

\begin{tabular}{l}
\hline Retained by government \\
\hline Land Acquisition Risk \\
\hline Planning Risk \\
\hline Increased Cost Risk \\
\hline Sub-sovereign or Parastatal Risk \\
\hline
\end{tabular}

Table 10. Risk transferred to private partner

\begin{tabular}{l}
\hline Transferred to private partner \\
\hline Design Risk \\
\hline Sponsor Risk \\
\hline Financial Parameter Ris \\
\hline Technology Risk \\
\hline Utility Risk \\
\hline Risk of demand (lower than estimation) \\
\hline Natural disaster (causing delay) \\
\hline $\begin{array}{l}\text { Defaulted developer (during the completion } \\
\text { of contract) }\end{array}$ \\
\hline Maintenance Risk \\
\hline
\end{tabular}

Based on the table above, the government retains fewer number of risk than the amount of risk transferred to the private partner.

Based on data from value for money calculation, the comparison table data can be shown in Table 11.

From the VfM value comparison result, BUMN assignment gives the lowest value compared to PPP or $100 \%$ financing by the state budget. The detailed calculation is attached.

By using the Quantitative Analysis of VfM, we found out that the optimum VfM to determine the modality/financing scheme for infrastructure projects. The optimum VfM is by using the BUMN assignment scheme, compared to the other two options, where the potential saving reaches up to $46 \%$ or IDR 2.9 trillion compared to complete financing by state budget. This saving can be used for somewhere else more productive by using this financing scheme on this project.

\section{RECOMMENDATION FROM RESEARCH RESULT AND DISCUSSION}

This research tries to give some input on the BUMN assignment scheme regarding the 
potential government savings when compared to a $100 \%$ project financing using state budget (APBN/APBD) on a toll road project. Large risk values resulted in a large difference in the calculation of the modalities scheme for toll road project development.

By using the Quantitative Analysis of Value for Money, the optimum Value for Money can be considered for choosing the scheme of modalities/financing of infrastructure projects. By calculating the quantification of risk, the risks that affect the investment cost the most are mostly transferred to the private sector. The result of quantitative analysis of VfM shows that the BUMN assignment scheme gives the most optimum outcome with the value of potential government cost saving at $46 \%$ compared to complete project financing by state budget (APBN/APBD), and $40 \%$ if compared to PPP scheme. The risk factors that can affect the overall investment costs are quantified and the ones with the largest value of risk are allocated to the private partners.

Risk factors transferred to the private sector greatly affect the cost of investment so that based on the VfM analysis, this PalembangIndralaya Toll Road project should produce the most optimum value for money by using the BUMN assignment compared with APBN/APBD funding or with PPP scheme.

This research underlines the benefit of using the VfM calculation before deciding a project financing scheme as it is directly related to the state financial condition. This research also found out that PPP scheme is more advantageous to $100 \%$ state budget financing for a road construction project. Therefore, it is very important to streamline the process for infrastructure investment or to create a government agency/body that focus on assisting investors/private sectors to invest in

Table 11. Analysis of Potential Government Saving. Comparative calculation of PSC, BUMN Assignment and PPP

\begin{tabular}{|c|c|c|c|c|c|}
\hline Skenario & $\begin{array}{c}100 \% \\
\text { Government }\end{array}$ & $\begin{array}{c}35 \% \text { Loan : } 65 \% \\
\text { Government }\end{array}$ & $\begin{array}{c}30 \% \text { Loan : } 70 \% \\
\text { Government }\end{array}$ & $\begin{array}{c}25 \% \text { Loan : } 75 \% \\
\text { Government }\end{array}$ & Ppp \\
\hline & PsC & $\begin{array}{l}\text { Bumn } \\
\text { Assignment }\end{array}$ & $\begin{array}{l}\text { Bumn } \\
\text { Assignment }\end{array}$ & $\begin{array}{l}\text { Bumn } \\
\text { Assignment }\end{array}$ & Ppp \\
\hline Capex & $2,692,981$ & & & & \\
\hline Opex & $2,994,829$ & & & & \\
\hline $\begin{array}{l}\text { Availability } \\
\text { Payment }\end{array}$ & - & $3,697,076$ & $3,981,467$ & $4,265,857$ & $5,234,851.44$ \\
\hline \multicolumn{6}{|l|}{ Risk Value } \\
\hline $\begin{array}{l}\text { Competitive } \\
\text { Neutrality }\end{array}$ & & $(521,265)$ & $(446,799)$ & $(372,332)$ & $(1,489,330)$ \\
\hline Retained Risk & 93,231 & 93,231 & 93,231 & 93,231 & 93,231 \\
\hline $\begin{array}{l}\text { Transferable } \\
\text { Risk }\end{array}$ & 645,044 & 225,765 & 193,513 & 161,261 & \\
\hline Total & $6,426,085$ & $3,494,807$ & $3,821,412$ & $4,148,017$ & $3,838,752$ \\
\hline Money Saving & - & $2,931,278$ & $2,604,673$ & $2,278,068$ & $2,587,332$ \\
\hline $\begin{array}{l}\text { Government } \\
\text { Saving }\end{array}$ & $0 \%$ & $46 \%$ & $41 \%$ & $35 \%$ & $40 \%$ \\
\hline
\end{tabular}


the infrastructure projects. Business entities may make this research a reference or a second opinion in preparing a risk-based project financing for their subsequent projects. More detailed research can be conducted on nonbankable infrastructure projects to attract more private sectors.

REFERENCES

BAPPENAS. (2011). Sustaining Partnership. Jakarta: Edisi Khusus Tahapan KPS.

Burger, Burger, P., \& Hawkesworth, I. (2011). How to Attain Value for Money : Comparing PPP and Traditional Infrastructur Public Procurement. OECD Library.

Grimsey, G., \& Lewis, M. K. (2005). Are Public Private Partnership Value for Money? Evaluating Alternative Approaches and Comparing Acadenic and Practitioner Views. Accounting Forum, 345-378.

Grout, P. A. (2005). Value for Money measurement in public-private partnerships. United Kingdom.

Hana, \& Negoro, N. (2014). Evaluasi Value for Money (VfM) pada Proyek Publik di Surabaya. Institut Teknologi Surabaya.

IIGF Institute. (2016). Kerjasama Pemerintah Swasta di Indonesia Acuan Alokasi Risiko. Jakarta: IIGF Institute.

Indonesia, P. R. (2014). Perpres RI No. 100. Jakarta.

Morallos, D., Amekudzi, A., \& Meyer, M. (2008). Value for Money Analysis in US Transportation Public-Private Partnership.

Pangeran, M., \& Wirahadikusuma, R. (2010). Challenges in Implementing the public sector comparator for bid evaluation of PPP's Infrastructure Project Investment. 